\title{
Effect of Integral Finned Tube on Heat Transfer Characteristics for Cross Flow Heat Exchanger
}

\author{
Zena K. Kadhim \\ Professor of Wasit University \\ Iraq, Wasit, University of Wasit
}

\author{
Muna S. Kassim \\ Asst. Prof. University of Al \\ Mustansirya \\ Iraq, Baghdad, University of Al \\ Mustansirya
}

\author{
Adel Y. Abdul Hassan \\ University of Wasit \\ Iraq, Wasit, University of Wasit
}

\begin{abstract}
The enhancement of heat transfer characteristics for cross flow heat exchanger with using low integral finned tube has been experimentally studied in this paper. The study includes designing and manufacturing of two test sections Each one has a single copper tube multi passes (eight passes). The first test section has the smooth copper tube with $(19 \mathrm{~mm})$ inner diameter and $(24 \mathrm{~mm})$ outer diameter. The second one has low integral finned tube with $(19 \mathrm{~mm})$ inner diameter, (21 $\mathrm{mm}$ ) root diameter and $(24 \mathrm{~mm})$ outer diameter . the fin height is $(1.5 \mathrm{~mm})$, thickness $(1 \mathrm{~mm})$ and the pitch is $(2 \mathrm{~mm})$. Air were used as a cooling fluid passing across the test tube with a range of velocity $(1,2$, and 4$) \mathrm{m} / \mathrm{s}$. Water were flows inside the tube with a range of $(2,3,4,5$ and 6$) \mathrm{L} / \mathrm{min}$. The water temperatures at the inlet of test tube were $(50,60,70,80){ }^{\circ} \mathrm{C}$. The study concluded that the heat transfer coefficient for cross flow heat exchanger is increasing when using low integral finned tube over the use of smooth tube.
\end{abstract}

\section{General Terms}

Ai: inner surface area of tube $\left(\mathrm{m}^{2}\right)$, Ao: outer surface area of tube $\left(\mathrm{m}^{2}\right), \mathrm{Cp}$ :, Specific heat of the fluid $\left(\mathrm{J} / \mathrm{kg} .{ }^{\circ} \mathrm{C}\right)$, d: tube diameter (m), hi: inner side heat transfer coefficient $\left(\mathrm{W} / \mathrm{m}^{2}{ }^{\circ} \mathrm{C}\right), \mathrm{Re}_{\mathrm{a}}$ : air side Reynolds number, ho: air side heat transfer coefficient $\left(\mathrm{W} / \mathrm{m}^{2} .{ }^{\circ} \mathrm{C}\right)$, ho $\mathrm{f}_{\mathrm{f}}$ : air side heat transfer coefficient for finned tube $\left(\mathrm{W} / \mathrm{m}^{2} .{ }^{\circ} \mathrm{C}\right)$, hos : air side heat transfer coefficient for smooth tube $\left(\mathrm{W} / \mathrm{m}^{2} .{ }^{\circ} \mathrm{C}\right) \mathrm{K}$ : thermal conductivity of tube material $\left(\mathrm{W} / \mathrm{m} .{ }^{\circ} \mathrm{C}\right), \quad \mathrm{K}_{\mathrm{w}}$ : thermal conductivity of water $\left(\mathrm{W} / \mathrm{m} .{ }^{\circ} \mathrm{C}\right), \mathrm{L}$ : length of tube $(\mathrm{m})$. , $\mathrm{Nu}_{\mathrm{a}}$ : air side Nesselt number, $\mathrm{Nu}_{\mathrm{w}}$ : inner side Nesselt number, $Q$ : heat transfer rate (Watt), R: thermal resistance, $\mathrm{Re}_{\mathrm{w}}$ : inner side Reynolds number, T: temperature $\left({ }^{\circ} \mathrm{C}\right)$, Ts: surface temperature $\left({ }^{\circ} \mathrm{C}\right)$, Tm: mean temperature $\left({ }^{\circ} \mathrm{C}\right)$, Ui: inner side overall heat transfer coefficient $\left(\mathrm{W} / \mathrm{m}^{2}{ }^{\circ} \mathrm{C}\right)$, Uo: air side overall heat transfer coefficient $\left(\mathrm{W} / \mathrm{m}^{2}{ }^{\circ} \mathrm{C}\right), \mathrm{u}_{\mathrm{w}}$ : velocity of water $(\mathrm{m} / \mathrm{s}), \dot{\mathrm{m}}$ : mass flow rate $(\mathrm{kg} / \mathrm{s}), \Delta \mathrm{T}$ : temperature difference $\left({ }^{\circ} \mathrm{C}\right), \rho_{\mathrm{w}}$ : density of water $\left(\mathrm{Kg} / \mathrm{m}^{3} \mu_{\mathrm{w}}\right.$ : visocity of water $(\mathrm{kg} / \mathrm{m} . \mathrm{s})$.

\section{Keywords}

Integral fin, Heat transfer coefficient, Enhancement, Turbulent flow, Cross flow.

\section{INTRODUCTION}

The energy conversion is associated with the power plants, units cooling, refrigeration and air condition, aerospace and automobiles, the need to enhance the heat transfer rates has become strongly needed because it's related to saving of energy, decrease the period of operation and increase the equipment life. heat exchanger is essential component of these systems. Heat exchanger is a tool which used for transfer enthalpy between two or more fluids[1]. The function of optimal heat exchanger is to make maximum possible heat transfer rate all together with minimum cost, minimum pressure losses, and with reduce the size of the part. In a heat exchanger the heat flows from hot temperature to cold temperature region by conduction from side to side in the wall, however, it's convection heat transfer equipment, because its performance are governs by convection which it always forced. Many techniques were used to increase the heat exchangers thermal performance thereby increasing energy, affecting material, decreasing the cost and minimizing the size. These technique are called (heat transfer enhancement). Enhancement techniques have three catagories:[2](passive, active, compouned method). Fins is one of the passive techniques which often used in heat exchanging systems to increase the rate of heat transfer with the surrounding. Externally finned tubes are commonly in the case that one of the fluids in a heat exchanger has much higher heat transfer coefficient than the other. Fins are a conventional method for increasing the heat transfer coefficient on the air-side by increase the heat transfer surface, increasing the mixing of fluid, by increasing the vortices and turbulence of flow, or by limiting the boundary layers growth near the surfaces in order to reduce the air side thermal resistance of the heat exchanger. Integral fins are extruded from the tube metal. The tube is generally made of (aluminum or copper, and its alloys) because these metals are soft and easily worked.[3]. Since the fins are extruded from the tube, Hence, the thermal contact resistance will be avoided.

Choi, et al [4] studied the characteristics of heat transfer on air side of heat exchanger with discrete plate finned-tube, the results showed higher $\mathrm{j}$-factors for the discrete plate finned tube heat exchanger than the continuous plate finned-tube heat exchanger due to higher flow mixing intensity and boundary layer break.

Ayad [3] presented an experimental study of the heat transfer characteristics for air cooled cross flow multi passes single aluminum tube (smooth tube and integral finned tube) from results, the enhancement ratio for finned tube was (1.86) for eight passes and (2.38) for four passes.

Tahseen, et al [5] investigated the forced convection heat transfers and air flow around the banks of in-line flat tube with laminar regime. The results showed increase the average Nusselt number $(23.7 \%-36.7 \%)$ with Reynolds number increasing from (527 to 880), The results also showed decreasing the pressure drop with Reynolds number increase.

\section{OBJECTIVES OF THE RESEARCH}

\subsection{The Aims}

This study aims to enhance the heat transfer coefficient on the air side for heat exchanger and to perform the low integral finned tube. 


\subsection{The Scope}

Design the test loop cross flow heat exchanger to obtain the flow and heat transfer coefficient for smooth and integral low finned tube, manufacture two conformal test sections from Pyrex, the first with smooth tube and the second with low integral finned tube, the experimental measurements effect for different air velocity the test tube passes, water flow rate inside tube and inlet water temperature on heat transfer coefficient for a smooth and integral low finned tube, using the thermal imager to visualize the above cases (study the average surface temperature), data analysis and quantification of complete measuring process, develop empirical correlations for Nusselt number for air side of low integral finned tube as function of Reynold's number, Prandtl's number and for hot water and nanofluid.

\section{THEORITICAL EQUATIONS}

The heat transfer rate are computed by heat balance according to first law of thermodynamic:[6]

$Q=\dot{m}_{h} C_{p h}\left(T_{h i}-T_{h o}\right)=\dot{m}_{c} C_{p c}\left(T_{c o}-T_{c i}\right)$

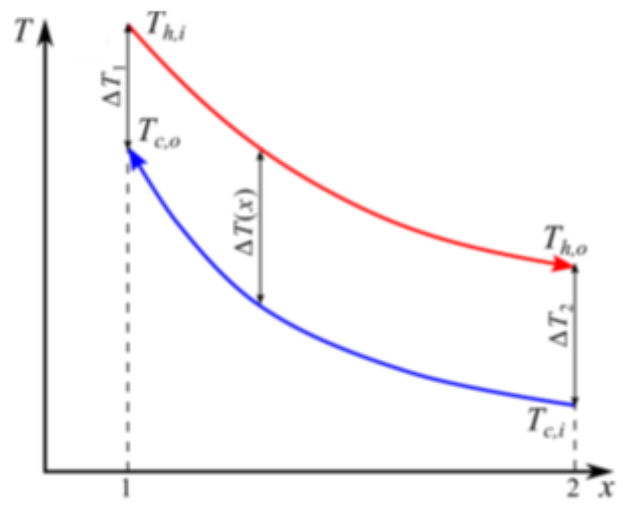

Fig. (1) Temperature profiles in a counter-flow.

Logarithmic mean temperature difference is estimate from the relation [7]:

LMTD $=\frac{\Delta T_{1}-\Delta T_{2}}{\ln \left(\Delta T_{1} / \Delta T_{2}\right)}=\frac{\Delta T_{2}-\Delta T_{1}}{\ln \left(\Delta T_{2} / \Delta T_{1}\right)}$

The overall heat transfer coefficient is a reciprocal of total thermal resistance of two fluids separated by a wall. [8].

$R_{\text {total }}=R_{o}+R_{\text {wall }}+R_{i}$

$R_{\text {total }}=\frac{1}{h_{o} A_{o}}+\frac{\ln \left({ }^{d_{o}} / d_{i}\right)}{2 \pi K L}+\frac{1}{h_{i} A_{i}}$

$Q=\frac{\Delta T_{m}}{R_{\text {total }}}=U A \Delta T_{m}=U_{i} A_{i} \Delta T_{m}=U_{o} A_{o} \Delta T_{m}$

The above expression can be reducing to.

$\frac{1}{R_{\text {total }}}=U A=U_{i} A_{i}=U_{o} A_{o}$

Sub. The equation (3.11) in (3.13)

$U A=U_{i} A_{i}=U_{o} A_{o}=\frac{1}{\frac{1}{h_{o} A_{o}}+\frac{\ln \left({ }^{d o} / d_{i}\right)}{2 \pi K L}+\frac{1}{h_{i} A_{i}}}$

the average surface temperature is calculated according to expression:

$T_{s}=\frac{T_{1}+T_{2}+T_{3}+\cdots+T_{n}}{n}$
The calculation of inner side heat transfer coefficient (turbulent flow) for water is achieved by:[9]

$h_{i}=\frac{Q}{A_{i} \times\left(T_{m}-T_{s}\right)}$

$T_{m}=\frac{\left(T_{h i}+T_{h o}\right)}{2}$

Then, the inner side Nusslte's number can be calculated as follows:

$N u_{w}=\frac{h_{i} \times d_{i}}{K_{w}}$

Reynolds number for water side.

$R e_{w}=\frac{\rho_{w} u_{w} d_{i}}{\mu_{w}}$

Prandtle number for water side.

$\operatorname{Pr}_{w}=\frac{\mu_{w} C_{p w}}{K_{w}}$

For smooth tube, $\left(\mathrm{h}_{\mathrm{o}}\right)$ can be determined as:. [3], [10]

$h_{o}=\frac{1}{\frac{1}{U_{o}}-\frac{d_{o} \ln \left(d_{o} / d_{i}\right)}{2 k}-\frac{d_{o}}{h_{i} d_{i}}}$

For low integral finned tube

$h_{o}=\frac{1}{\frac{1}{U_{o}}-\frac{d_{o} \ln \left(d_{r} / d_{i}\right)}{2 K}-\frac{d_{o}}{h_{i} d_{i}}}$

the expression Reynolds number for air side,

$R e_{a}=\frac{\rho_{a} u_{a} d_{h}}{\mu_{a}}$

$d_{h}=\frac{4 \times \text { cross sectional area of the air duct }}{\text { perimeter of the air duct }}$

Cross sectional area of the air duct $\left(A_{c}\right)$,

$A_{c}=W \times H$

Perimeter of the air duct $(\mathrm{P})$

$P=(W+H) \times 2$

Prandtle number for air side of tube:

$\operatorname{Pr}_{a}=\frac{\mu_{a} C p_{a}}{K_{a}}$

Nusslte number for air side:

$N u_{a}=\frac{h_{o} d_{o}}{K_{a}}$

Percentage of enhancement:

$$
h_{o} \%=\frac{h_{o f}-h_{o s}}{h_{o s}} \times 100
$$

\section{EXPERIMENTAL APPARATUS}

The experimental test rig is designed and manufactured to satisfy the requirements of the test system for a smooth and integral low finned tube.

\subsection{Test Section}

The experimental work includes designing and manufacturing of two test sections from Pyrex glass, each one has rectangular cross section with the dimensions $(250 \times 500 \times 1200) \mathrm{mm}$ width, height and length, respectively, figure (2) show a photograph of test tube. Each one has single 
copper tube multi passes (8 passes) with $(250 \mathrm{~mm})$ length, passing horizontally through the test duct, , and the distance between center to center of passes is $(55 \mathrm{~mm})$. The first one has a smooth copper tube with $(19,24) \mathrm{mm}$ inner and outer diameters respectively. The second one has an integral low finned copper tube of (8) passes with $(19,21,24) \mathrm{mm}$ inner, root and outer diameters respectively. The height of fin's is $(1.5 \mathrm{~mm})$ with a thickness of $(1 \mathrm{~mm})$ and pitch $(2 \mathrm{~mm})$ A plane of test tube is shown in figure (3), lathe machine were used to manufacture the finned tubes.

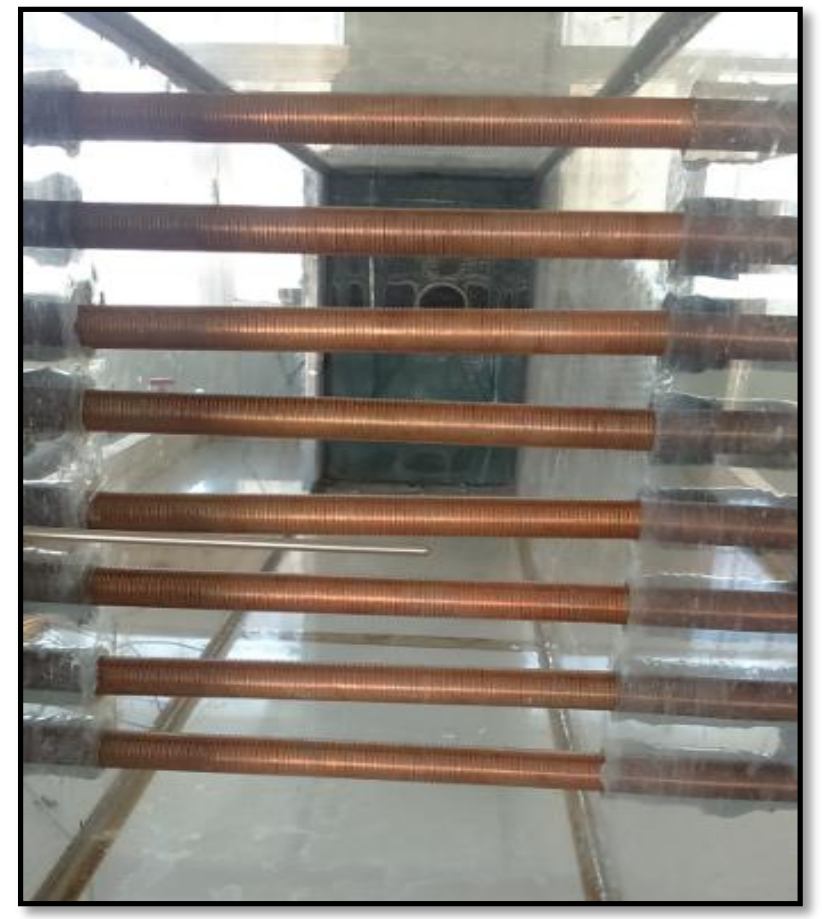

Fig. (2) photograph of test tube.

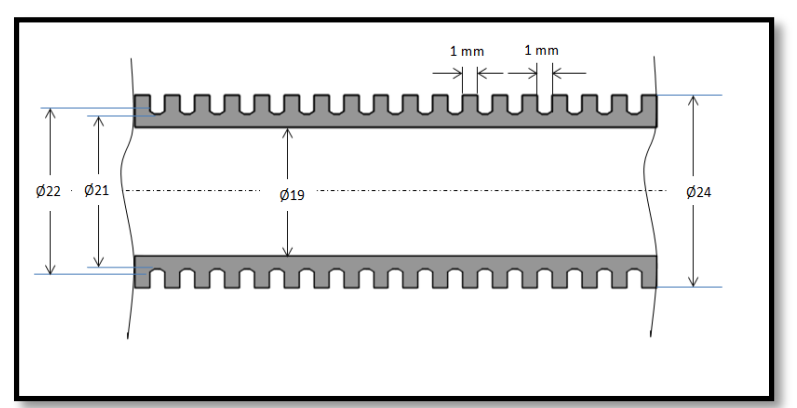

Fig. (3) Plane of low integral finned tube.

\subsubsection{The Air Flow And Water Loop Systems.}

The air flow system consists of centrifugal blower to deliver the air to the test section, diffuser and air duct is manufactured by a galvanized steel used to supply the air to test section.

The water loop system consist of water pump used for pushing the hot water to the test tube, Water Heater to supply hot water and an insulated water tank of dimensions (200x200x400) mm (16 liter) capacity manufactured from a galvanized steel and very well insulated by glass wool, the tank is used circulate hot water (supply water to the water pump and receive water from test tube). Fig. (4) show a schematic diagram of water loop system with measurements and Fig. (5) show a schematic diagram of air supply system with counter. While Figure (6) shows photograph of experimental test rig.

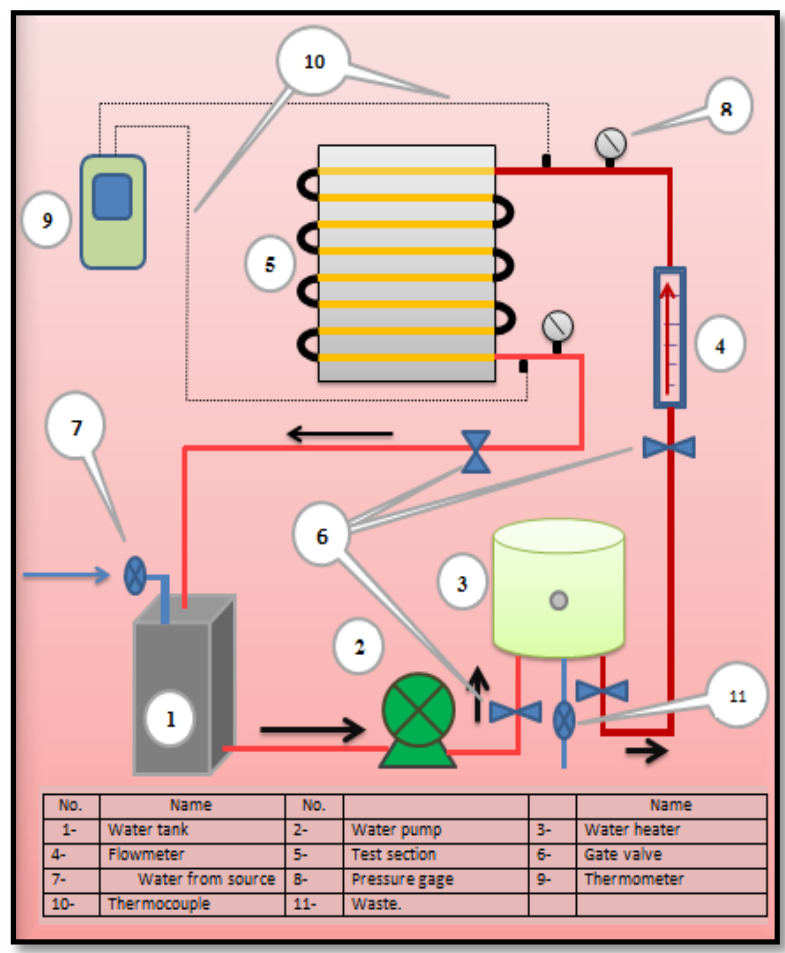

Fig. (4) Schematic diagram of water loop system with measurements.

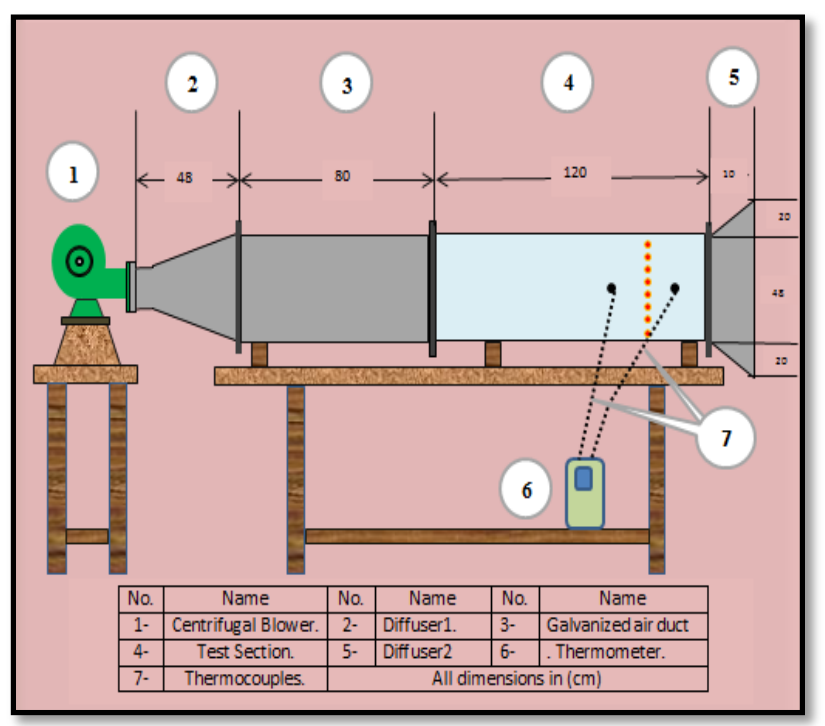

Fig. (5) Schematic diagram of air supply system with counter. 


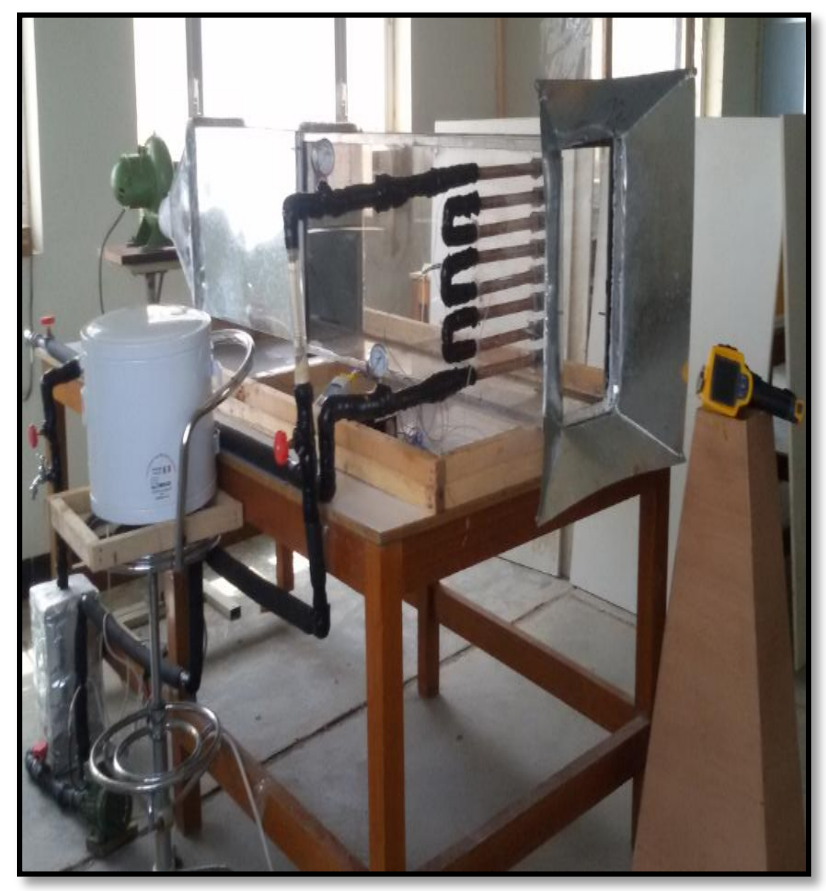

Fig. (6) Photograph of experimental test rig.

\subsection{Measurement Devices}

The temperature measuring device used in the present work are:

A four- channel temperature recorder, two thermocouples type (K) (-100 to 1300$){ }^{\circ} \mathrm{C}$ are immersed the inlet and outlet of the test tube are used to measure the temperature of hot fluid at these locations and two temperature probes of (K-type, $\mathrm{Ni} \mathrm{Cr}-$ $\mathrm{Ni} \mathrm{Al})$ having a temperature range of $(0-800){ }^{\circ} \mathrm{C}$ are used for measuring the air temperature at the inlet and outlet of test section.

The other measurement devices are:

[hot-Wire anemometer, flow meter, thermometer, pressure gauges, and thermal imager].

Fig (7) shows the photography of Four- channel temperature recorder, and Fig (8) shows the photograph of thermal imager.

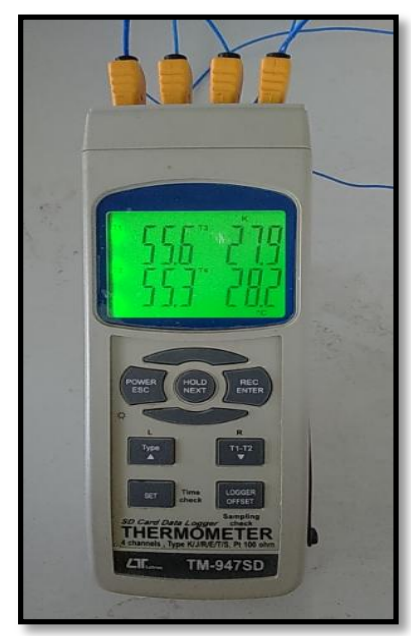

Fig.(7 ) Photograph of Four- channel temperature recorder.

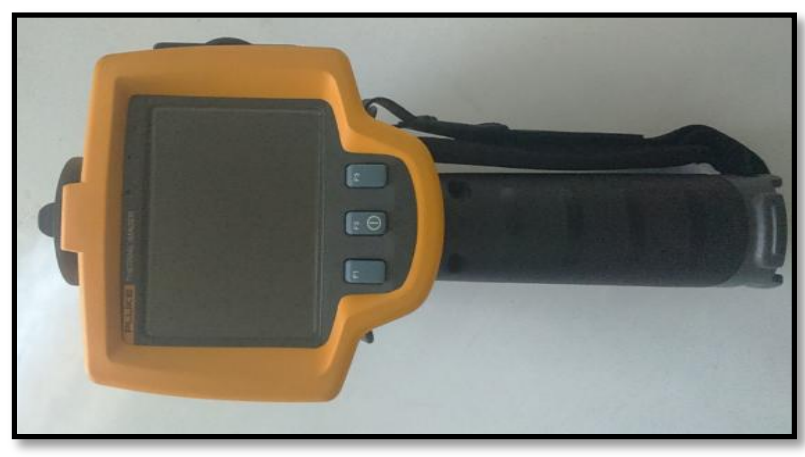

Fig (8) Photograph of thermal imager.

\subsection{Uncertainty Analysis}

The experimental uncertainties must be given proper attention in the experimental research, The method proposed by Kline and McClintock [11] seems to be widely accepted among the authors of technical papers.

The maximum measurement uncertainties were: heat dissipation rate $(-6.98 \%$ to $7.61 \%)$, inner side Reynold's number $(-3.41 \%$ to $1.47 \%)$, inner side heat transfer coefficient $(-9.25 \%$ to $15.31 \%)$, air side Reynold's number $(-5.07 \%$ to $7.92 \%)$ and air side heat transfer coefficient $(-7.46 \%$ to $7.24 \%)$

\section{RESULTS AND DISCUSIONS}

Figures ( 9 and 10) shows the relation of heat dissipation rate and the temperature of inlet water at four air velocities for smooth and low integral finned tube. It's clear from these figures that the heat dissipation rate $(\mathrm{Q})$ is improved with increasing of (Twi), the increase in water temperature causes an increment in tube temperature. For the same cooling air temperature, this leads to increase in temperature difference which directly proportional to heat rate. Also, it shows the increasing of heat dissipation with increasing of air velocity, due to increase in Reynolds number of air caused by increase of heat transfer coefficient of air. On the other hand, a comparison between the two figures show that the heat dissipation rate of finned tube is higher than for smooth tube at the same boundary conditions.

Figure (11) illustrate the variation of water side heat transfer coefficient $\left(\mathrm{h}_{\mathrm{i}}\right)$ with Reynolds number of water at different inlet water temperatures, the figure show increasing of heat transfer coefficient $\left(h_{i}\right)$ with increasing of water Reynolds number due to increasing of the flow turbulence.

Figure (12) shows a comparison of heat dissipation rate for smooth and integral finned tube for different air velocities, it's clear from these figures that the heat dissipation rate for the finned tube was higher than for smooth tube for similar boundary conditions. This is due to the increasing of surface area of dissipation and penetrates of boundary layers near the tube wall due to configuration of the fins. The maximum percentage of enhancement of $\left(\mathrm{Q}_{\mathrm{f}}\right)$ was $(72.05 \%)$ greater than $\left(\mathrm{Q}_{\mathrm{s}}\right)$.

A comparison of air side overall heat transfer coefficient $\left(\mathrm{U}_{\mathrm{o}}\right)$ for smooth and integral finned tube for different air velocities is shown in figure (13). The overall heat transfer coefficient for air side increasing with increasing the air velocity, as well as, clarifies the $\left(\mathrm{U}_{\mathrm{o}}\right)$ for finned tube is higher than for smooth tube at similar boundary conditions. These increments occur as a result of increasing of $\left(\mathrm{U}_{\mathrm{i}}\right)$ caused by increasing of heat dissipation rate. The maximum percentage of enhancement for ( $\mathrm{U}_{\mathrm{o}}$ finned) was $(79.21 \%)$ greater than $\left(\mathrm{U}_{\mathrm{o}}\right.$ smooth). 
Figure (14) shows a comparison of heat transfer coefficient for smooth and integral finned tube for air side with different air velocities, it's obvious from these figures that $\left(h_{0}\right)$ increases with increasing of air velocity, this is due to increasing of Reynolds number which indicates to increasing of turbulence of flowing air near the tube wall. On the other hand, the $\left(h_{0}\right)$ for finned tube is greater than for smooth tube at similar boundary conditions. This due to increasing in the air side Reynold's number and heat transfer surface area and due to the penetrates of boundary layers near the wall of tube which caused by the configuration of the fins. The maximum percentage of enhancement for $\left(h_{o}\right.$ finned $)$ was $(100.93 \%)$ above $\left(\mathrm{h}_{\mathrm{o} \text { smooth }}\right)$.

Figure (15) illustrate a comparison of air side Nusselt's number for smooth and integral finned tube for different air side Reynold's number. It's clear that air side Nusselt number increases with increasing of Reynold's number due to increasing of turbulence of flowing air near the tube wall. The maximum percentage of enhancement $\left(\mathrm{Nu}_{\mathrm{a}}\right.$ finned $)$ was $(100.1 \%)$ higher than $\left(\mathrm{Nu}_{\mathrm{a} \text { smooth }}\right)$.

\section{CONCLUSIONS}

The following comments could be concluded:-

- The heat dissipation rate $(\mathrm{Q})$ are increase with the increase of inlet water temperature, increasing of cooling air velocity.

- The heat dissipation rate for the finned tube was greater than for smooth tube, The maximum percentage of enhancement of $\left(Q_{\text {finned }}\right)$ was $(72.05 \%)$ greater than $(Q$ smooth).

- The inner side heat transfer coefficient is increased with the increase of water Reynolds number.

- The air side heat transfer coefficient for low integral finned tube is higher than for smooth tube at the same air velocity. the maximum of enhancement was $(100.93 \%)$ over the smooth tube.

- The air side Nusselt's number for low integral finned tube is higher than for smooth tube at the same Reynolds number. the maximum of enhancement was $(100.1 \%)$ over the smooth tube.

- Emperical correlations for water side and air side Nusselt's number where predicted in this study:

For water side

$N u_{w}=0.035 R e_{w}{ }^{0.76} \operatorname{Pr}_{w}{ }^{0.216}$

For air side

$N u_{a}=6.5 \operatorname{Re}_{a}{ }^{0.4} \operatorname{Pr}_{a}{ }^{2.57}$

The above correlations are valid for turbulent flow with the following ranges of Reynolds number

$3800 \leq R e_{w} \leq 17800$

$21450 \leq R e_{a} \leq 86400$

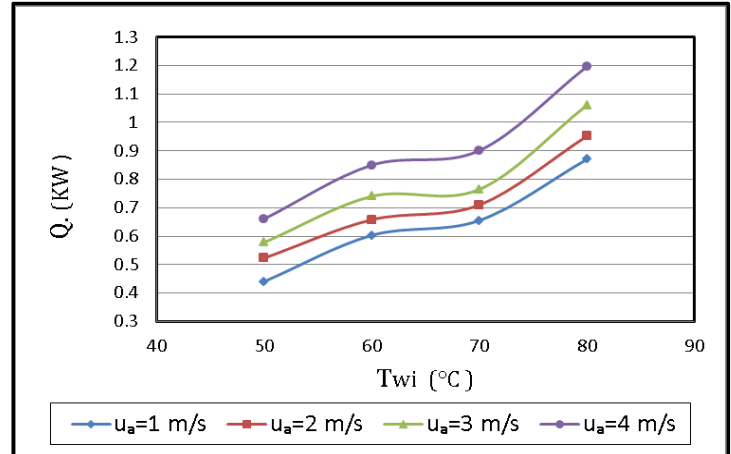

Fig. (9) Variation of heat dissipation rate with inlet water temperature for smooth tube at different air velocities.

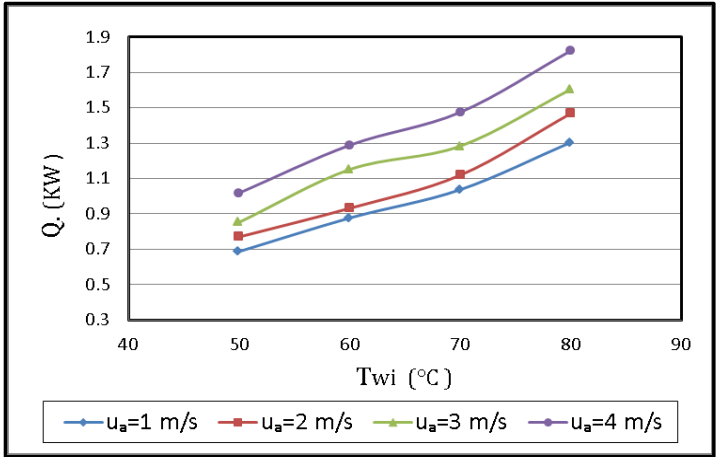

Fig. (10) Variation of heat dissipation rate with inlet water temperature for integral finned tube at different air velocities.

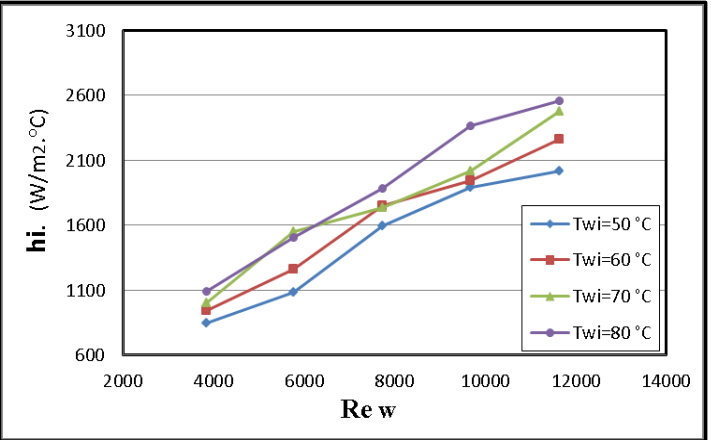

Fig. (11) Variation of water side heat transfer coefficient with water Reynolds number.

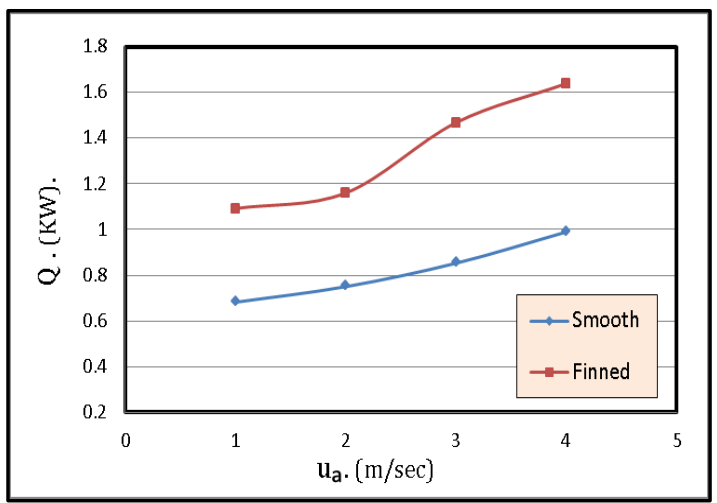

Fig. (12) Comparison of heat dissipation rate for smooth and integral finned tube for different air velocities. 


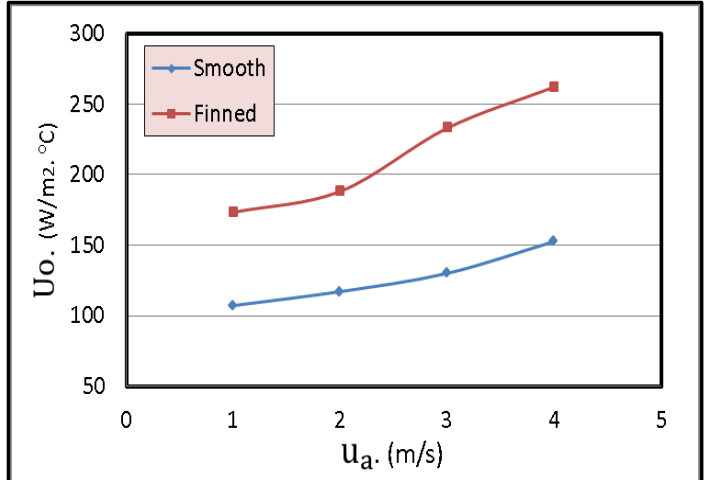

Fig. (13) Comparison of Overall heat transfer coefficient for smooth and integral finned tube for different air velocities.

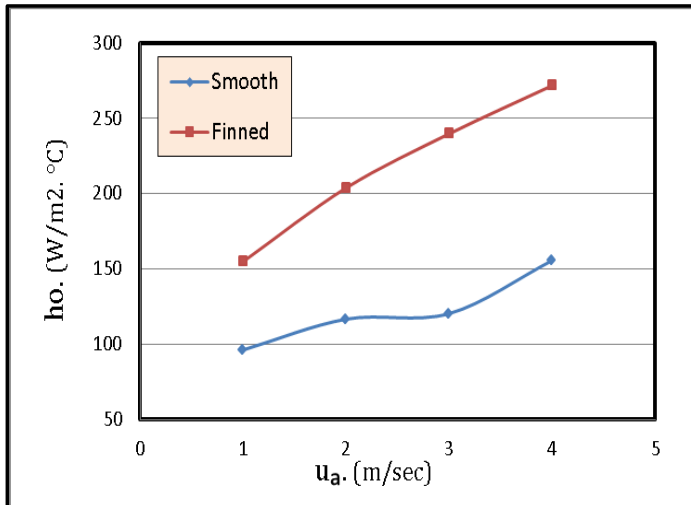

Fig. (14) Comparison of air side heat transfer coefficient for smooth and integral finned tube for different air velocities.

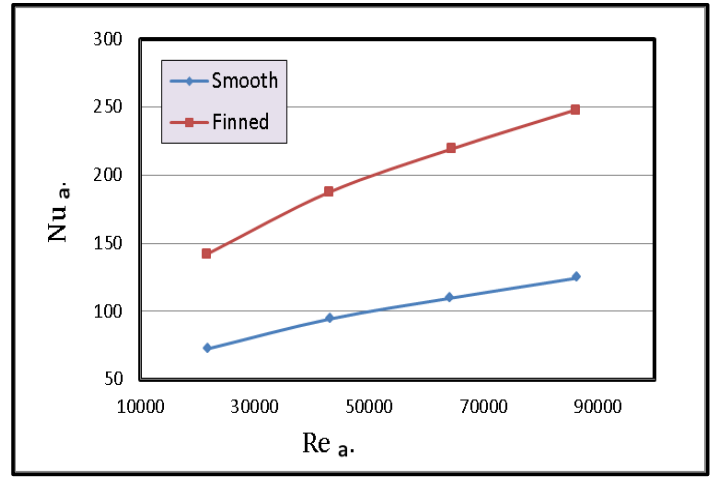

Fig. (15) Comparison of air side Nusselt's Number for smooth and integral finned tube for different air side Reynold's number.

\section{ACKNOWLEDGMENTS}

I would like express deepest gratitude to submit my thanks to all members of the ( College Of Engineering / Mechanical Engineering Department at the University Of Wasit )for their cooperation.

\section{REFERENCES}

[1] R. K. Shah \& D. R Sekulib, "Heat Exchangers", Handbook of Heat Transfer, 3rd ed.,(Rohsenow W. M., Hartnett, J. P., and Cho, Y. I., eds.), McGraw-Hill, New York, Chap. 17, pp.17.3, 1998.

[2] A. E. Bergles, "Techniques to Enhance Heat Transfer ", Handbook of Heat Transfer, 3rd ed.,(Rohsenow W. M., Hartnett, J. P., and Cho, Y. I., eds.), McGraw-Hill, New York, Chap. 11, pp.11.1-11.76, 1998.

[3] Ayad Mezher Rahmah, " Experimental Study of an Integral Finned-Tube Heat Exchanger", MSc, thesis, University of Technology, Iraq, 2011.

[4] J. M. Choi, Y. Kim, M. Lee, Y. Kim, "Air side heat transfer coefficients of discrete plate finned-tube heat exchangers with large fin pitch", Applied Thermal Engineering 30 (PP. 174-180), 2010.

[5] Tahseen Ahmad Tahseen, M. Ishak and M. M. Rahman, "An Experimental Study Air Flow And Heat Transfer Over In-Line Flat Tube Bank", International Conference on Mechanical Engineering Research (ICMER2013), 2013.

[6] Incropera, Dewitt, Bergman and Lavine, "Fundamentals of Heat and mass Transfer, Sixth Edition, 2006.

[7] J.P. Holman, "Heat Transfer", Sixth edition, McGrawHill Co.,.p.p 536-537, 1986.

[8] Wessam Falih Hasan, "Theoretical and Experimental Study to Finned Tubes Cross Flow Heat Exchanger", MSc, thesis, University of Technology, 2008.

[9] Osamah Mahdi Jasim,"Parametric Investigation of Heat Transfer Enhancement in Helical Coil Tube by Using Vortex Generators (Coil Wire inserts) and Nanofluids", M.Sc. Thesis, University of Al Mustansiriya, 2014.

[10] J. F. Seara, F. J. Uhı'a, R. Diz and A. Dopazo, "Condensation of R-134a on Horizontal Integral-Fin Titanium Tubes", Applied Thermal Engineering, 30, pp.295-301, 2010.

[11] S. J. Kline and F. A. McClintock, "Describing Uncertainties in Single-Sample Experiments", Mechanical Engineering, Vol. 75, No. 1, pp.3-8, 1953. 